\title{
Word Association and Its Function at the Constituent Understanding on the Language Learning
}

\section{Arti Prihatini}

University of Muhammadiyah Malang, Malang

\section{Abstract}

This paper aimed at describing word association and its function at the constituent understanding on the language learning. Word association is a relation between a word with other words because of the semantic relationship. A word association test appears when there is a stimulus word and someone mentions a response word that comes to mind firstly based on the stimulus word. The response words show someone's mental lexicon as a result of language acquisition and language learning. Word associations can be used in the process of understanding constituents (linguistic units) with word association tests, they are (1) words, (2) phrases, and (3) sentence patterns. In word

Corresponding Author: Arti Prihatini

artiprihatini@umm.ac.id

Received: 17 February 2020

Accepted: 20 February 2020

Published: 27 February 2020

Publishing services provided by Knowledge E

(c) Arti Prihatini. This article is distributed under the terms of the Creative Commons

Attribution License, which permits unrestricted use and redistribution provided that the original author and source are credited.

Selection and Peer-review under the responsibility of the Isolec Conference Committee.
S OPEN ACCESS constituent learning, word association tests are carried out by asking questions so that the result can show the semantic networks of words that are classified by word type. Phrase constituent learning is also held by asking questions, but response words are included before or after the stimulus word so that these words form a phrase. Meanwhile, sentence constituent learning is held by presenting words that are located as predicate and then asking questions that bring up the subject, object, complement, or additional information that accompany the predicate. With this method, students do not only learn constituents as units that have levels from small (words) to large ones (sentences), but also understand that constituents have a patterned and interconnected system.

Keywords: word associations, constituents, language learning

Constituents are some linguistic units that can combine to form larger constituent. Constituents consist of sounds, syllables, words/morphemes, phrases, clauses, sentences, and discourses. These constituents are interconnected. Pallier, Devauchelle, and Dehaene (2011: 2522) state, "based on the perspective of linguistic analysis, sentences do not only consist of words, but also have hierarchical structures that are interconnected one another." Furthermore, syntactic constituency structures are recursive representations using sets in one or more linguistic units so that at each level, each constituent acts syntactically (Rambow, 2010: 336).

Language learning requires constituent understanding. Students need to understand the structure of words, phrases, and sentences. In each curriculum, constituents 
are taught by a certain learning design. In the 2013 curriculum, the constituents are integrated on every text learning. For example, definition sentences and description sentences are learnt in the observation-report-texts learning or nouns and adjectives are learnt in the description texts learning.

Every constituent does not separate one another, but every constituent has an association with other constituent. For example, a word has a semantic relationship with other words. The word makan (eat) has a semantic relationship with nasi (rice), roti (bread), lapar (hungry), and kenyang (full). The word makan has a predication-argument relationship with word nasi and roti because makan is predicate, while nasi and roti are located as arguments. The word lapar (hungry) and kenyang (full) have a causal relationship with makan because if someone is hungry, he will eat so that he is full. It can be concluded that the semantic relationship of the word is integrated by various other words. So that, these words form a semantic network that is establish a spider web.

Word associations can be applied to find out the semantic network. Word associations are presented by a stimulus word and then someone is asked to write down one response word that comes to mind firstly based on the stimulus word. As stated by Istifçi (2010: 360), Rapp (2014: 2030) and Playfoot (2018: 607), word association tests are performed by showing a stimulus word and then someone is asked to mention other word after hearing or reading the stimulus word.

The response of the word association can represent someone's mental lexicon, which is a collection of vocabulary that has been installed in the human brain. Mental lexicon is not only obtained by language acquisition, but also by language learning. So that, verbal knowledge is arranged in the mental lexicon. As Jackendoff (2002: 130) argues that the mental lexicon is a store of words in long-term memory related to grammar in composing phrases and sentences, containing information such as speech (home is a noun), denotation (a dog is an animal), pronunciation (balloon pronounced b-lōōn '), affective meaning (cake is something I like), and so on.

Therefore, these word associations can be used for understanding constituents in language learning. So that students can comprehend the characteristics and the structures of words, phrases, and sentences. The constituent learning is adjusted by the student needs and difficulty level of the material. Based on that background, this article discusses word association and its function at the constituent understanding on the language learning. 


\section{Word Association}

A word association is a relationship between a word and another words that show the semantic relationship among these words. The word presented is called the stimulus word, while the word that appears in the mind firstly after reading/hearing the stimulus word is called the response word. Meara (2009: 21) explains that word association can be carried out by presenting one stimulus word, then someone need to respond with the word that appears in the mind firstly. The type of word used as a stimulus word can be a noun, verb, adjective, or numeral. In this regard, Bahar and Hansell (2015: 352) explained that in the free word association test, the important thing that needs to be explained is the characteristics of the response word to each stimulus word.

The stimulus word and response words have various semantic relationships. The relationship between the stimulus word and the response word can be analysed by the semantic relations, such as synonym, antonym, hypernym, and hyponym. In addition, the relationship between stimulus words and response words can be analysed based on the class of words used. Meara (2009: 6) states that word associations consist of two types, namely (1) paradigmatic associations and (2) syntagmatic associations. In paradigmatic associations, the stimulus word makan (eat) will be responded by minum (drink). In the syntagmatic association, the stimulus word makan (eat) will be responded by nasi (rice). In this regard, Playfoot (2018: 622) suggests that word association analysis can be associated by word frequency effects, concrete/abstract properties, word classes, and categories that are often considered to be responses (paradigmatic and syntagmatic) to provide a deeper understanding regarding the structure and the dynamics of the lexicon.

\section{Word Association and Its Function at the Constituent Understanding on the Language Learning}

Word associations can be used in the process of understanding constituents in language learning starting from words, phrases, and sentences. Bucklin and Daniel (2017:668) stated that students' preconception of some learning topics can be identified by the association technique. So that, word association can represent students' mental lexicon that can be utilized to understand the structure and the system of the constituents as follows. 


\subsection{Word Association and Its Function at The Word Constituent Understanding}

Words are constituents that consist of two type, namely free words and bound words. These words can compose larger constituents, namely phrases and sentences. The free word consists of several types, namely nouns, verbs, adjectives, and adverb. Sneddon et. al. (2010: 132) explains that nouns represent living things, animals, goods, place names, or abstract things. Verbs represent actions or circumstances. Adjectives contain the characteristics of a noun (Sneddon et. al., 2010: 180). Numerals represent number or scale. The bound word consists of several types, namely prepositions and conjunctions. Prepositions usually precede nouns, while conjunctions connect one constituent with other constituents.

In word constituent learning, word association tests are carried out by asking questions so that the response words can represent a semantic networks of the stimulus word. The response words are classified by word type. The learning process of word constituent can be illustrated as follows.

TABLE 1: The Learning Process of The Word Constituent.

\begin{tabular}{|l|c|c|c|c|}
$\begin{array}{c}\text { 1. Provide a } \\
\text { picture/photo/ } \\
\text { video! }\end{array}$ & \multicolumn{3}{|c|}{ 2. Ask some questions that bring up answers to certain word } \\
classes!
\end{tabular}

Based on Table 1, these respose words have semantic relationship. The adjectives describe the characteristics of the nouns. The verbs represent activity that can be done by the noun. The numerals describe the number or the scale of the nouns. Based on Table 1, students can comprehend word classes and the semantic relation and the semantic construction with the other word classes. Sukartiningsih (2010: 213) stated that word association can be defined as the phenomena of the semantic construction of a word. 


\subsection{Word Association and Its Function at The Phrase Constituents Understanding}

Phrases are constituents that are consist of two or more words. Phrases are constructed by a head/core phrases and a modifier. The phrase consists of two types, namely (1) endocentric phrases and (2) exocentric phrases. Endocentric phrases consist of two or more free words which have meaning as the head and the modifier, while exocentric phrases consist a bound word as the head and two or more words as the modifier. Bauer (2008: 35) suggests that endocentric phrases have a clear head (core phrases), while exocentric phrases do not have a head (core phrase) or actually have a head but the relationship is external because of one of the words that composes it is a bound word. For example, in phrase apel hijau (green apple), the word apel is the head that belongs to the noun, while the word hijau is a modifier that belongs to the adjective. The phrase is an endocentric phrase because apel and hijau are free words that have meaning.

Phrase constituent learning is also carried out by asking questions, but the response words can be embedded before or after the stimulus word to form the phrase. The learning process of understanding phrase constituent can be illustrated as follows.

TABLE 2: The Learning Process of The Phrase Constituent.

\begin{tabular}{|c|c|c|c|c|c|}
\hline \multicolumn{2}{|c|}{ 1. Provide a stimulus word! } & \multirow{2}{*}{$\begin{array}{l}\text { 2. Write down } \\
\text { the response } \\
\text { words! }\end{array}$} & \multicolumn{2}{|c|}{ 3. Determine the phrase structure! } & \multirow{2}{*}{$\begin{array}{l}\text { 4. Conclude } \\
\text { the type of } \\
\text { the phrase! }\end{array}$} \\
\hline Word Type & Stimulus Word & & & & \\
\hline \multirow[t]{2}{*}{ Noun } & Cuaca (weather) & Cerah (bright) & Cuaca (head) & Cerah (modifier) & Noun phrase \\
\hline & Biru (blue) & Tua (old) & Biru (head) & Tua (modifier) & Noun phrase \\
\hline \multirow[t]{2}{*}{ Adjective } & Sangat (very) & $\begin{array}{l}\text { Cantik } \\
\text { (beautiful) }\end{array}$ & Sangat (modifier) & Cantik (head) & $\begin{array}{l}\text { Adjective } \\
\text { phrase }\end{array}$ \\
\hline & Baik (good) & Sekali (very) & Baik (head) & Sekali (modifier) & $\begin{array}{l}\text { Adjective } \\
\text { phrase }\end{array}$ \\
\hline \multirow[t]{2}{*}{ Verb } & Sudah & Belajar (learn) & Sudah (modifier) & Belajar (head) & Verb phrase \\
\hline & Makan (eat) & Lagi (adverb) & Makan (head) & Lagi (modifier) & Verb phrase \\
\hline \multirow[t]{2}{*}{ Numeralia } & Dua (two) & Mata (eyes) & Dua (head) & Mata (modifier) & $\begin{array}{l}\text { Numerals } \\
\text { phrase }\end{array}$ \\
\hline & 12 & Meter (meter) & 12 (head) & Meter (modifier) & $\begin{array}{l}\text { Numerals } \\
\text { phrase }\end{array}$ \\
\hline
\end{tabular}

Based on Table 2, most of the response words are free word or content word. Fernandez and Cairns (2011: 64) states that content word can be a noun, verb, adjective of adverb. Content word and function word are stored separately. Content word and 
function word are accessed differently. Based on this condition, teacher can improve constituent learning so that students can understand content word and function word.

\subsection{Word Association and Its Function at The Sentence Constituents Understanding}

Sentences are constituents that have complete meaning. At least, the sentence structure consists of SP (subject, predicate) or SPO (subject, predicate, object). The presence or absence of an object depends on the predicate used. If the predicate is an intransitive verb, the object is not needed. If the predicate is a transitive verb, an object is needed. Fisher (2002: 262) explains that the verb will determine the structure of the sentence. The verb determines the subject and the object that can appear in the clause, and how they will be interpreted.

The sentence constituent learning is carried out by presenting the word that is located as a predicate, registering the response words, then arranging the response words into the subject, object, complement, or additional information that can be embedded to the predicate. By this method, students do not only learn constituents as a unit that has hierarchical levels from words to sentences, but also understand that constituents have certain patterns and interconnected systems. The learning process of understanding sentence constituents can be illustrated as follows.

TABLE 3: The Learning Process of The Sentence Constituent Understanding

\begin{tabular}{|c|c|c|c|c|c|}
\hline \multirow{2}{*}{$\begin{array}{l}\text { 1. Provide a } \\
\text { stimulus } \\
\text { word! } \\
\text { Stimulus } \\
\text { Word }\end{array}$} & \multirow{2}{*}{$\begin{array}{l}\text { 2. Write down } \\
\text { the response } \\
\text { words! } \\
\text { Response Word }\end{array}$} & \multicolumn{4}{|c|}{ 3. Ask questions based on the stimulus word and the response words! } \\
\hline & & $\begin{array}{l}\text { Who does the } \\
\text { activity? }\end{array}$ & $\begin{array}{l}\text { What is being } \\
\text { done? }\end{array}$ & $\begin{array}{l}\text { What is the } \\
\text { object of the } \\
\text { activity? }\end{array}$ & $\begin{array}{l}\text { How does the } \\
\text { activity carried } \\
\text { out? }\end{array}$ \\
\hline makan (eat) & $\begin{array}{l}\text { Citta } \\
\text { ibu (mother) } \\
\text { minum (drink) } \\
\text { ayam (chicken) } \\
\text { cepat (fast) } \\
\text { susu (milk) } \\
\text { teratur (regular) }\end{array}$ & $\begin{array}{l}\text { Citta } \\
\text { ibu (mother) }\end{array}$ & $\begin{array}{l}\text { makan (eat) } \\
\text { minum (drink) }\end{array}$ & $\begin{array}{l}\text { ayam (chicken) } \\
\text { susu (milk) }\end{array}$ & $\begin{array}{l}\text { dengan cepat } \\
\text { (fastly) } \\
\text { dengan teratur } \\
\text { (regularly) }\end{array}$ \\
\hline \multicolumn{2}{|c|}{ 4. Determine sentence patterns! } & Subject & Predicate & Object & $\begin{array}{l}\text { Additional } \\
\text { Information }\end{array}$ \\
\hline
\end{tabular}

In this example, the verb is used as a stimulus word because the verb is the core of the sentence that determines the subject and object. As Fraser (2013: 64) argues that all constituents that appear at the sentence level are depend on the main verb of the clause. In other words, the verb will determine whether the subject is animate 
or inanimate, does it require an object, and how many objects are needed. Fisher (2002: 266) explains that in the process of speech planning, the speaker coordinates the choice of verbs and sentence structure to produce output that can be interpreted.

\section{Conclusion}

Based on the description of word association and its function at the constituent understanding on the language learning, constituents are language unit that have hierarchical structure from word, phrase, and sentence. Word association can be used as a strategy on understanding the constituent in language learning. Stimulus words and response words from the word association can be utilized to learn the type of words, phrases, and sentences. Based on this strategy, constituents can be learned as a unity of language that has a system, a hierarchical structure, and an interconnected system.

\section{Suggestion}

Based on the description of this paper, teachers are suggested to utilize the word association for enhancing the constituent understanding on the language learning. Teachers can manage the class with an interactive and fun learning strategy to explain the interconnected system of the constituents. Furthermore, next researchers are suggested to expand the research about the utilization of word associations in other topics of the language learning in order to students can comprehend the language system properly and comprehensively.

\section{Acknowledgments}

The author intended to express gratitude and appreciation to University of Muhammadiyah Malang that has provided motivation and support for the researcher.

\section{References}

[1] Bahar, M., \& Hansell, M. H. 2000. The Relationship between Some Psychological Factors and Their Effect on the Performance of Grid Questions and Word Association Tests. Educational Psychology, 20 (3), 349-364. doi: 10.1080/713663739

[2] Bauer, Laurie. 2008. English Exocentric Compound. Dany Amiot (ed). La Composition Dans Une Perspective Typologique page. 35-47. Arras: Artois Presses Université. 
[3] Bucklin, C. J., \& Daniel, K. L. 2017. Using Word Associations as a Formative Assessment for Understanding Phylogenetics. The American Biology Teacher, 79(8), 668-670. https://abt.ucpress.edu/content/79/8/668.abstract

[4] Fernandez, Eva M. dan Cairns, Helen Smith. 2011. Fundamentals of Psycholinguistics. West Sussex: Wiley Blackwell.

[5] Fisher, C. 2002. The Role of Abstract Syntactic Knowledge in Language Acquisition: A Reply to Tomasello (2000). Cognition, 82(3), 259-278.

[6] Fraser, A., Schmid, H., Farkas, R., Wang, R., \& Schütze, H. 2013. Knowledge Sources for Constituent Parsing of German, A Morphologically Rich and Less-Configurational Language. Computational Linguistics, 39(1), 57-85.

[7] Istifçi, Ilknur. 2010. Playing With Words: A Study on Word Association Responses. Uluslararasi Sosyal Arastırmalar Dergisi (The Journal of International Social Research). Volume 3 (10): 360-368. Retrieved from http://www.sosyalarastirmalar. com/cilt3/sayi10pdf/istifci_ilknur.pdf

[8] Jackendoff, R. 2002. Foundations of Language: Brain, Meaning, Grammar, Evolution. New York: Oxford University Press.

[9] Meara, Paul M. 2009. Connected Words: Word Associations and Second Language Vocabulary Acquisition. Amsterdam, Philadelphia: John Benjamins Publishing.

[10] Pallier, C., Devauchelle, A.-D., \& Dehaene, S. 2011. Cortical Representation of The Constituent Structure of Sentences. Proceedings of the National Academy of Sciences, 108(6), page 2522-2527. doi:10.1073/pnas.1018711108

[11] Playfoot, D., Balint, T., Pandya, V., Parkes, A., Peters, M., \& Richards, S. 2018. Are Word Association Responses Really the First Words that Come to Mind? Applied Linguistics Vol. 39 (5): 607-624. doi:10.1093/applin/amw015

[12] Rambow, Owen. 2010. The Simple Truth about Dependency and Phrase Structure Representations: An Opinion Piece. In Human Language Technologies: The 2010 Annual Conference of the North American Chapter of the Association for Computational Linguistics Los Angeles, California pages 337-340.

[13] Rapp, R. 2014. Using Word Familiarities and word associations to Measure Corpus Representativeness. In Proceedings of the Ninth International Conference on Language Resources and Evaluation (LREC-2014), Reykjavik, Iceland, page. 20292036.

[14] Sneddon, J. N. et. al. 2010. Indonesian: A Reference Grammar 2nd Edition. Sydney: Allen \& Unwin

[15] Sukartiningsih, Wahyu. 2010. Konstruksi Semantis Kata pada Perkembangan Bahasa Indonesia Anak. Bahasa dan Seni, Vol. 38 (2): 205-216. 